Bugher, J. C. (1934). Amer. F. Cancer, 21, 809.

Cahan, W. G. (1955). Amer. $\dot{7}$. Surg., 89, 494.

Dibble, P. A., and Chambers, R. G. (1960). Laryngoscope (St. Louis), 70, 1647 .'

Dowling, G. B. (1955) - Brit. 7. Derm., 67, 275.

Eisenstaedt, I. S. (1938). F. Amer. med. Ass., 110, 2056

Eisenstaedt, J. S. (1938). F. Amer. med. Ass., 110, 2056.

Epstein, S. S., and Shaw, H. J. (1958). Cancer (Philad.), 11, 326.
Ewing, J. (1940). Neoplastic Diseases : A Treatise on Tumors, 4th ed. p. 20. Saunders, Philadelphia.

Fried, B. M. (1958). Arch. Surg., 77, 730

Gabriel, W. B. (1963). The Principles and Practice of Rectal Surgery, 5 th ed., p. 490. Lewis, London.

Hellendall, H. (1943). Amer. F. Surg., 60, 22.

Hurt, H. H., and Broders, A. C. (1933). 7. Lab. clin. Med., 18, 765.

Killingback, M., Wilson, E., and Hughes, E. S. R. (1965). Aust. N.Z. 7. Surg., 34, 178.

Kirshbaum, J. D., and Shively, F. L. (1938). 7. Lab. clin. Med., 24, 283.

Kolmeier, K. H., and Bayrd, E. D. (1963). Proc. Mayo Clin., 38, 523.

Lane, W. A. (1909). Quoted by Bacon (1945).
Lund, C. C. (1933). New Engl. 7. Med., 209, 1144.

Morganti, G., and Cresseri, A. (1954). Sang, 25, 421.

Peller, S. (1941). Amer. F. Hyg., 34, 1.

Slaughter, D. P. (1946). Surgery, 20, 133.

Sneddon, I. B. (1963). Brit. med. F., 2, 405

Stalker, L. K., Phillip, R. B., and Pemberton, J. (1939). Surg. Gynec. Obstet. 68, 595 .

Stertz, G. (1916). Berl. klin. Wschr., 53, 489.

Stertz, G. (1916). Berl. klin. Wschr., 53, 489.
Videbaek, A. (1947). Heredity in Human Leukaemia and its Relation to Cancer. Lewis, London.

Wallace, A. F. (1957). Brit. 尹. Surg., 45, 165.

Warren, S., and Ehrenreich, R. (1944). Cancer Res., 4, 554.

- and Gates, O. (1932). Amer. F. Cancer, 16, 1358.

Watson, T. A. (1953). Cancer (Philad.), 6, 365.

Werthamer, S., Jabush, M., and Schulman, J. (1961). f. Amer. med. Ass., 175, 558.

Williams, R. C. (1959). Ann intern. Med., 50, 1174.

Wooley, P. G. (1903). Boston med. surg. Y., 148, 1.

Wynder, E. L., Bross, I. J., and Day, E. (1956). Cancer (Philad.), 9, 86.

\title{
Case of Myxoedema with a Huge Pericardial Effusion and Cardiac Tamponade
}

\author{
LAURENCE MARTIN,* M.D., F.R.C.P. ; G. S. SPATHIS, † B.M., M.R.C.P.
}

\section{Brit. med. F., 1965, 2, 83-85}

It has been known for many years that hypothyroidism affects the heart according to its degree of severity. When it is mild or of recent origin a sinus bradycardia may be the only finding, but in severe or long-standing cases the heart may be grossly enlarged, and congestive failure, a pericardial effusion, and eleotrocardiographic changes may be present, giving rise to the condition of " myxoedema heart." The clinical findings are variable and the underlying pathological changes ill-defined because myxoedema of sufficient duration or severity to present with predominant cardiac manifestations usually occurs in the middle-aged or elderly - mainly women-who of ten have hypertensive or ischaemic heart disease as well. Thus there is doubt whether myxoedema per se can cause heart failure (Hamolsky et al., 1963 ; McBrien and Hindle, 1963), but there is no doubt that gross enlargement of the heart may be found, and in some cases this is certainly due to a pericardial effusion.

The object of this communication is to record a case of severe myxoedema in which a huge pericardial effusion produced cardiac tamponade, and to comment upon certain features in the light of what is known about myxoedema heart and the aetiology of the associated pericardial effusion.

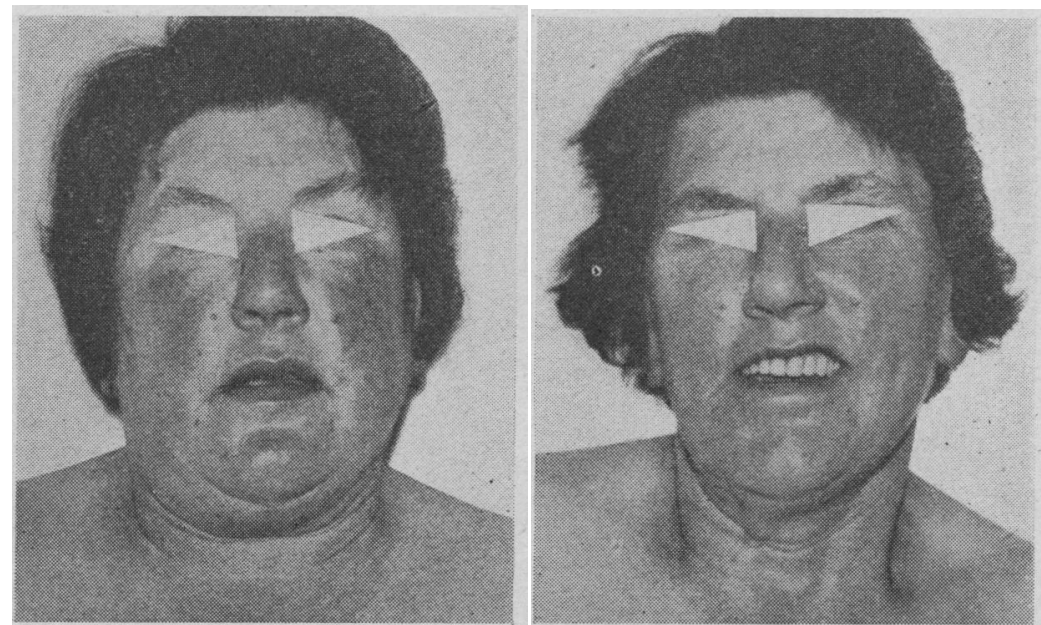

Fig. 1.-Photograph of patient, October Fig. 6.-Photograph of patient, October 1963.

\section{Case Report}

A spinster aged 57 was admitted to hospital on 17 October 1963. Her main complaints were of gain in weight to $13 \mathrm{st} .5 \frac{1}{2} \mathrm{lb} .(85 \mathrm{~kg}$.), swelling of the legs, and constipation.

She had attended as an out-patient in December 1949, when her weight was $11 \mathrm{st} .3 \mathrm{lb}$. $(71.2 \mathrm{~kg}$.), and complained of colicky lower abdominal pain and increasing constipation. Apart from a rectum loaded with faeces, nothing abnormal was found. A barium enema revealed a colon of large calibre with poor evacuation, but it was not a true megacolon. Liquid paraffin and enemata as required were advised. She was not seen again until her admission to hospital, when she was evidently grossly myxoedematous. She then revealed that she had taken thyroid extract from infancy until 1952, when she had stopped it. This explained why hypothyroidism did not show at her out-patient attendance in 1949. Inquiry at the Victoria Hospital for Children, where she had been taken in infancy and where thyroid therapy had been started, was unavailing, as their old records had been destroyed during the war of 1939-45.

On examination she was bloated, plethoric, and evidently myxoedematous (Fig. 1). Her voice was gruff, her skin was dry, and her legs were swollen with pitting oedema to the thighs. Jugular veins were distended beyond the angles of the jaw without visible pulsation. Pulse was 100, regular; blood-pressure $230 / 145$, settling to $160 / 130$ a few hours later. Apex beat was impalpable; heart sounds were faint but normal. Coarse rales were heard at both lung bases. Tendon reflexes were active, but the ankle-jerks were notably pendular. $X$-ray examination of the chest showed an enormous heart shadow, virtually filling the left lower hemi-thorax (Fig. 2).

By the next day (18 October) the pulse had fallen to 90 but showed a paradox effect, her blood-pressure readings being $165 / 115$ during expiration and 155/ 120 on inspiration. A pericardial effusion with tamponade was diagnosed. The urinary output remained low and her weight increased despite relief dyspnoea by bed rest. An E.C.G. showed electrical alternans and low voltages, with flat or inverted $T$ waves and slight $S$-T depression over the left ventricle (Fig. 3). Thyroid uptake of ${ }^{131} \mathbf{I}$ was $8 \%$

* Physician, Addenbrooke's Hospital, Cambridge.

† Late Medical Registrar, Addenbrooke's Hospital, Cambridge. Now Registrar to Department of Metabolic Diseases, St. Thomas's Hospital, London. 
of the administered dose $(29.6 \mu \mathrm{c})$; plasma activity at 48 hours was $0.27 \% / 1$., of which $0.08 \% / 1$. was protein-bound.

On 21 October the pericardium was aspirated and some $1,500 \mathrm{ml}$. of fluid withdrawn. $X$-ray examination after the injection of $30 \mathrm{ml}$. of air demonstrated a fluid level. The size of the cardiac shadow was unchanged, and it was estimated that at least as much fluid remained as had been withdrawn. During the paracentesis the venous pressure, measured by a manometer in the right median cubital vein, fell from 16.5 to $2.5 \mathrm{~cm}$. The pericardial aspirate consisted of brownish-green fluid containing red cells, white cells, and methaemoglobin. Bilirubin content was $5.9 \mathrm{mg} . / 100 \mathrm{ml}$., Molisch reaction positive. Total protein content was 7 g. $/ 100 \mathrm{ml}$., urea $26 \mathrm{mg} . / 100 \mathrm{ml}$., sodium $138 \mathrm{mEq} / 1$., potassium $4.3 \mathrm{mEq} / \mathrm{l}$., chloride $101 \mathrm{mEq} / \mathrm{l}$., cholesterol $145 \mathrm{mg} . / 100 \mathrm{ml}$. On electrophoresis the fluid appeared like diluted normal serum: $\gamma$-globulin 5 turbidity units as compared with a serum $\gamma$-globulin of 24.5 units (normal 25-40), no abnormality on immuno-electrophoresis. Nuclear staining by fluorescent-antibody technique was weakly positive both

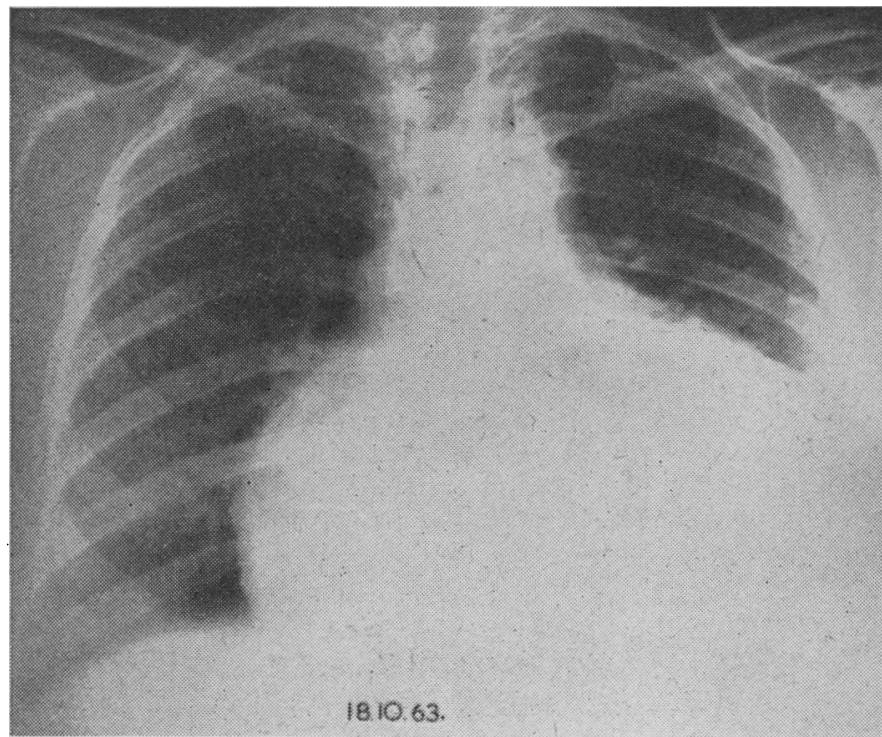

Fig. 2.-Radiograph taken on 18 October 1963 showing enormous heart shadow.

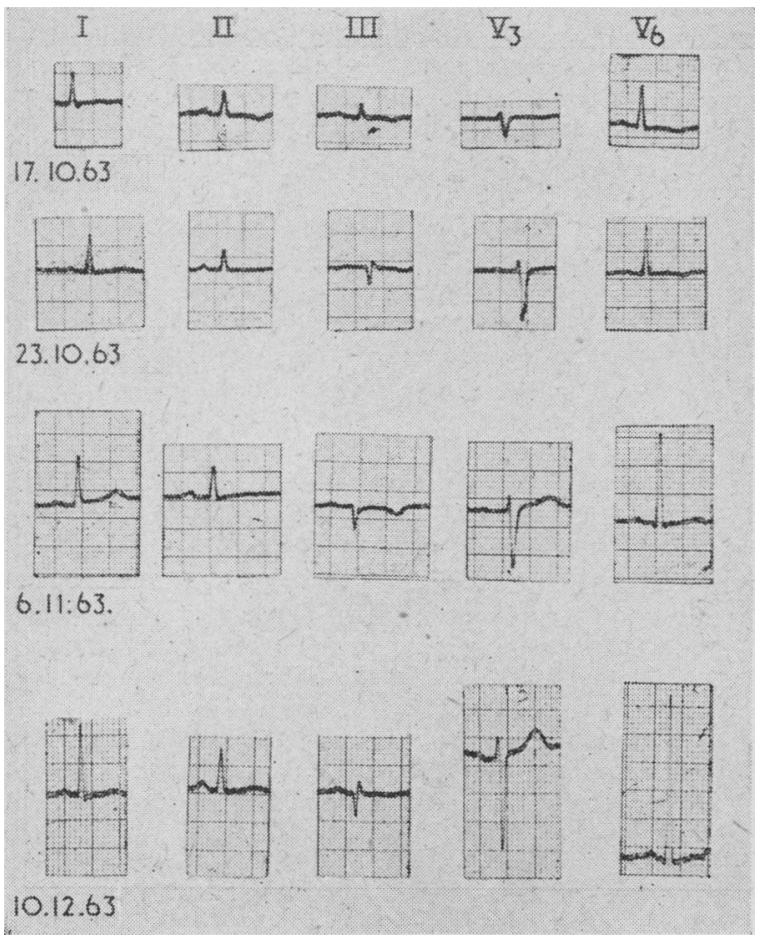

FIG. 3.-E.C.G. record. in blood and in pericardial aspirate. L.E. cells were absent. (Dr. P. J. Lachmann.)

Treatment consisted of thyroxine alone, begun on 20 October with $0.05 \mathrm{mg}$. daily and increased at five-day intervals by $0.05 \mathrm{mg}$., so that on discharge she was taking $0.25 \mathrm{mg}$. daily in divided doses.

The first effect of pericardial aspiration was a copious diuresis, reduction of the oedema, and a corresponding loss of weight (Fig. 4). The dyspnoea was relieved, but the mental and physical states remained sluggish.
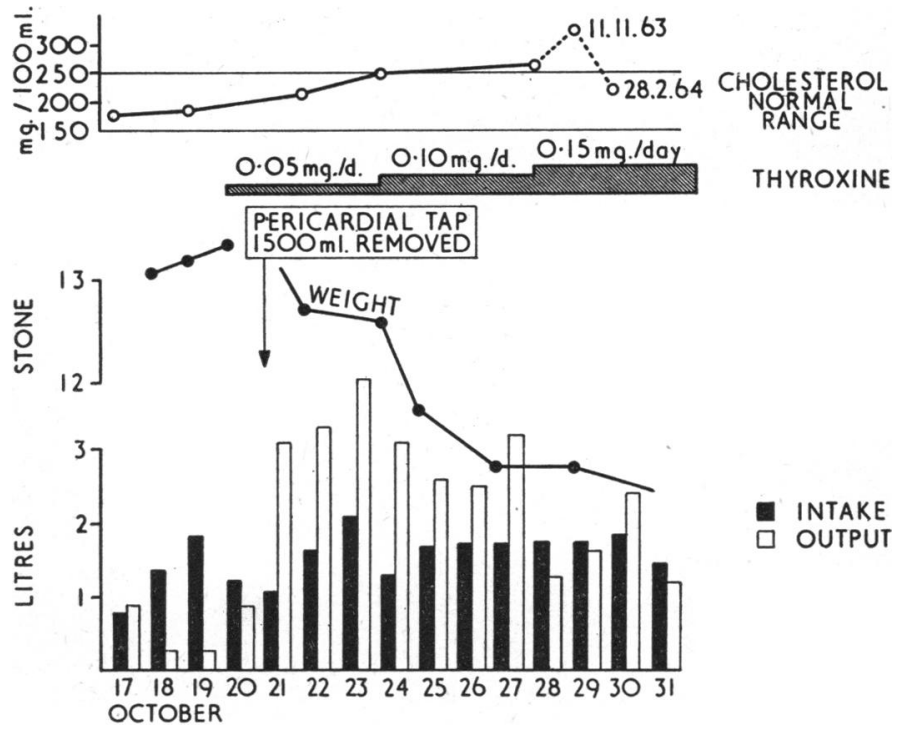

INTAKE $\square$ OUTPUT

FIG. 4.-Chart showing progress of case.

The E.C.G. showed no immediate change after paracentesis save that the electrical alternans was abolished. Two days later, however, the QRS complexes were larger ( $R$ in V6 $2.4 \mathrm{mV}$ and $S$ in V1 $3.8 \mathrm{mV}$ greater), some left axis deviation had developed, a positional $\mathrm{Q}$ wave appeared in III and IIIR, and the $\mathrm{P}-\mathrm{R}$ interval was unchanged at $0.16 \mathrm{sec}$. By 6 November more obvious changes were apparent; the P-R interval had increased to $0.2 \mathrm{sec}$, the $\mathrm{QRS}$ complexes showed higher voltages, and $T_{1 I I}$ was inverted although $\mathrm{T}$ in V5, 6 had become upright.

The plasma cholesterol rose steadily from $176 \mathrm{mg} . / 100 \mathrm{ml}$. before thyroxine therapy to $326 \mathrm{mg}$. on 11 November, a few days before discharge. Thereafter it fell to $230 \mathrm{mg}$. by 11 December and remained normal. When she was seen as an out-patient on

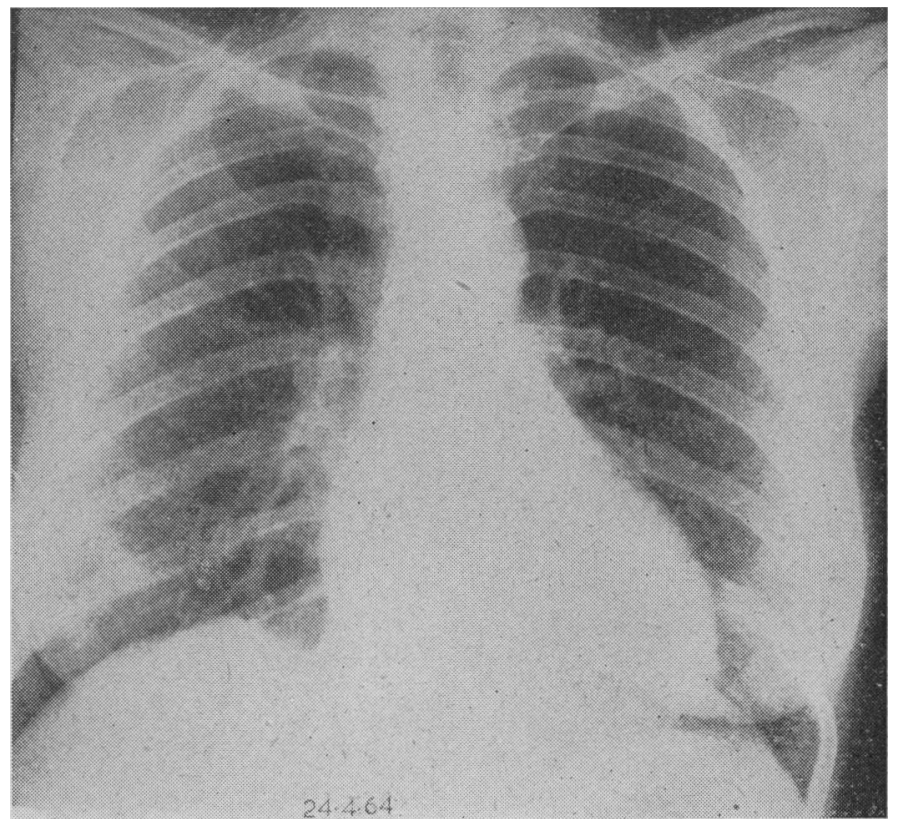

FIG. 5.-Radiograph taken on 24 April 1964. 
10 December the $P-R$ interval was 0.16 sec. and $T_{I I I}$ had become flat. The positional $Q$ persisted in III and IIIR, but in IIIR was 0.04 sec. duration and $1 \mathrm{mV}$ in size. $S_{\mathrm{v}}=22 \mathrm{mV}, \mathrm{R}_{\mathrm{v} 5}=21 \mathrm{mV}$, and $R v_{6}=28 \mathrm{mV}$. At this time the blood-pressure was $210 / 115$, the jugular venous pressure was raised about $1 \mathrm{~cm}$., and the ankles were slightly oedematous. By April 1964, however, these signs of mild failure had disappeared and the cardiac silhouette was smaller still, although she had continued to take thyroxine alone (Fig. 5).

When last seen, 23 October 1964, she weighed $10 \frac{1}{2}$ stones (66.7 kg.), was at work, and denied having any symptoms (Fig. 6).

\section{Discussion}

Zondek (1918) and Fahr (1925) were among the first to describe myxoedema heart. The cardinal features included generalized cardiac enlargement, which might be gross, a slow indolent action, distant sounds, poor pulsation on fluoroscopy, and E.C.G. changes. Physical signs suggestive of heart failure were often present, and the condition was believed to be a myocarditis which responded to thyroid therapy. Kern et al. (1949), however, reported four cases of myxoedema heart with pericardial effusions to which they attributed the cardiac enlargement. McBrien and Hindle (1963) emphasized the difficulty of distinguishing, on the basis of physical signs, between congestive heart failure and a pericardial effusion in myxoedema heart. They used the Valsalva manœuvre as a means of differentiation, in that a normal response but without reflex slowing was obtained in cases of myxoedema heart. The E.C.G. changes in myxoedema may be found in cases without cardiac enlargement, and they may be absent when there is slight or moderate cardiomegaly. But they are always present when the heart is grossly enlarged. Kern et al. (1949) went so far as to attribute the E.C.G. changes entirely to an associated pericardial effusion, but in our experience this is not so.

Certain features shown by our case merit comment as follows.

Pericardial fluid in cases of myxoedema heart has usually been described as straw-coloured, nearly clear, and of specific gravity 1012 to 1025 . White cells, mainly polymorphs at 488 / c.mm. were recorded in the fluid by Kern et al. (1949) and lymphocytes by Marzullo and Franco (1939). Red cells have rarely been found, but Gordon (1935) recorded a few in an amber-coloured fluid. The striking feature of the fluid in our case was the brownish-green colour and high bilirubin content, evidently due to altered blood, and the presence of red cells, white cells, and methaemoglobin. The blood may well have originated from abnormally fragile capillaries. Orr (1962) recorded bleeding in three cases of myxoedema coma in the form of melaena, epistaxis, cutaneous and gastrointestinal haemorrhages, and multiple small cerebral haemorrhages, which he attributed to increased capillary fragility.

The products of altered blood in our cases suggested that bleeding had been taking place for some time, and the presence of fresh red cells that it was continuing.

Tamponade.-We have been unable to find an undoubted case of tamponade recorded in the literature of myxoedema heart. Kern et al. (1949) commented on its rarity, which they explained by slow formation of the pericardial effusion and the ability of the pericardium to distend. Marks and Roof
(1953) recorded one case of myxoedema heart with pericardial effusion in which aspiration reduced the venous pressure from 140 to $60 \mathrm{~mm}$. and produced a diuresis. They did not specifically claim that tamponade existed, but from the pressure readings it seems likely to have been present. In our case we consider that bleeding, in addition to the formation of the pericardial effusion, may well have been a factor in the production of tamponade.

Diagnosis of Pericardial Effusion.-It is clear that the initial cardiac signs in our case were due to the pericardial effusion and tamponade. A dramatic diuresis and relief of dyspnoea followed the withdrawal of $1,500 \mathrm{ml}$. of pericardial fluid after bed rest for 48 hours had been ineffective. Pericardial aspiration did not reduce the size of the cardiac shadow, but subsequent thyroxine therapy alone did so. This was in keeping with the findings of Zondek (1918), Fahr (1925), and Kern et al. (1949). It is of interest that Fahr had considered, but rejected on radiological grounds, a pericardial effusion as the cause of the cardiomegaly in the first of his cases. But scrutiny of the $x$-ray reproductions suggests that a pericardial effusion may well have been present, and to-day few radiologists would dogmatically exclude pericardial effusion in a case of extreme generalized cardiac enlargement. It would seem, therefore, that a pericardial effusion should always be suspected in cases of myxoedema heart with gross enlargement and physical signs suggestive of congestive heart failure.

The E.C.G. changes in myxoedema are diverse, but some are characteristic. The combination of bradycardia with a featureless tracing of low voltage is typical. The P-R interval is of ten prolonged, and $\mathrm{A}-\mathrm{V}$ dissociation may be found. Atrial fibrillation, flutter, paroxysmal atrial tachycardia, and transient ventricular fibrillation have all been recorded. The QRS complexes are of small amplitude, a $Q$ wave is sometimes present in III-possibly positional or due to cardiac dilatation-and disappears after treatment. Perhaps the commonest and least specific change is flattening or slight inversion of the $T$ waves, particularly in II. During treatment they often invert more deeply, but this is sometimes due to unmasking of a strain pattern from associated ischaemia or hypertension. In our case (Fig. 3) the $\mathrm{T}$ waves became more deeply inverted with the beginning of treatment, but later became upright. This was assumed to be due to absorption of the pericardial effusion.

\section{Summary}

A case of myxoedema with a huge pericardial effusion and tamponade is described. Complete recovery followed pericardial aspiration and thyroxine therapy. Certain features of interest are discussed.

\section{REFERENCES}

Fahr, G. (1925). F. Amer. med. Ass., 84, 345.

Gordon, A. H. (1935). Trans. Ass. Amer. Physcns, 50, 272

Hamolsky, M. W., Kurland, G. S., and Freedberg, A. S. (1963). Current Concepts in Hypothyroidism, edited by K. R. Crispell, p. 138. Pergamon, London. Kern, R. A., Soloff, L. A., Snape, W. J., and Bello, C. T. (1949). Amer.

McBrien, D. J., and Hindle, W. (1963). Lancet, 1, 1066.

Marks, P. A., and Roof, B. S. (1953). Ann. intern. Med., 39, 230.

Marzullo, E. R., and Franco, S. (1939). Amer. Heart F., 17, 368.

Orr, F. R. (1962). Lancet, 2, 1012.

Zondek, H. (1918). Münch. med. W schr., 65, 1180. 